УДК [781.42: 786.2]: 78.071.1 (510)

DOI 10.34064/khnum2-2408

\title{
Члжан Менчжее
}

аспірантка кафедри інтерпретології та аналізу музики

Харківського національного університету мистецтв імені І. П. Котляревського

e-mail:764735303@qq.com

ORCID iD 0000-0003-0988-4263

\section{ПОЛІФОНІЧНІ ЖАНРИ У ФОРТЕПІАННІЙ ТВОРЧОСТІ КИТАЙСЬКИХ КОМПОЗИТОРІВ}

Попри те, щио XX cm. ознаменоване сплеском інтересу до поліфонії, а в другій його половині значно розширилась географія створення нових поліфонічних композицій, питання розвитку китайської поліфонічної музики для фортепіано залишаються майже не розкритими. Мета цього дослідження - виявити вклад китайських композиторів у створення фортепіанного поліфонічного репертуару $X X-$ початку XXI cm. Застосований комплексний дослідницький підхід, який поєднує історичні методи, щзо відбивають еволюиію музичного мислення, з теоретичними, щзо дозволяють розкрити жанрово-стильову специфіку творів китайських авторів. Результати дослідження представляють еволюиійні процеси розвитку китайської фортепіанної поліфонії, імена багатьох композиторів, які створили цікаві музичні зразки, жанровий спектр китайської фортепіанної поліфонічної музики. Резюмується, щзо китайські композитори в повній мірі оволоділи мистечтвом сучасного контрапункту, представленим жанрами поліфонічної програмної n'єси (Хе Лутін), інвениії (Сяо Шусянь, Ду Цянь, Сунь Юньїнн, Чен Ченкуанг), поліфонічної сюїти (Ма Гуй), великого поліфонічного ииклу (Хе Шаоін, Чень Хуадо, Сяо Шусянь), фуги (Лі Джунюн, Юй Суянь, Чень Ган, Тянь Лейлей, Дуань Пінтай, Чжен Чжун), малого ииклу «Прелюдія і фуга» (Дін Шанде, Чен Жимінг, Ван Лімань). Творчо освоюючи і переосмислюючи європейський досвід, китайські композитори наповнили свої поліфонічні твори яскраво начіональними рисами. 
Ключові слова: поліфонія; китайська фортепіанна музика; китайські композитори; інвенція; фуга; сюїта; прелюдія і фуга.

Постановка проблеми. Починаючи 3 XX століття, інтерес музикантів до поліфонії значно посилився. Це проявилося в зверненні багатьох композиторів до конструктивних принципів Бароко і математично точних прийомів контрапунктичної техніки. Зацікавленість сучасних авторів поліфонією пояснюється синтетичністю музичного мислення XX - початку XXI століття, що обумовлює, зокрема, відродження докласичних форм і жанрів та їх оновлення з метою адекватного відображення сучасного світобачення. Ця властивість сучасної музики визначає актуальність в наш час вищої форми поліфонії - фуги.

У другій половині XX ст. формуються нові національні композиторські школи, представники яких виявляють значний інтерес до написання поліфонічних творів для фортепіано. Серед маловідомих сьогодні митців є представники таких країн, як Аргентина, Греція, Японія, Китай та ін. Професійне художнє становлення багатьох китайських композиторів, що створювали поліфонічні п’єси для фортепіано, відбувалося протягом усього XX століття. Це - чималий шлях, що веде від прямого запозичення основ європейської теорії поліфонії до формування на базі набутих теоретичних знань національно самобутнього музичного напрямку. На сьогоднішній день поліфонічні твори для фортепіано становлять значну частину національного фортепіанного репертуару. Ці твори виконуються на концертній естраді, застосовуються в навчальному процесі, проте, вони мало вивчені музикознавцями.

Аналіз останніх досліджень за темою. Протягом ХХ століття китайськими і зарубіжними музикознавцями розглядалися питання поліфонії в музичному фольклорі (Wiant, 1936; 范醉嗯 [Fan Zuyin], 2004; Li Hong, 2015) і професійній китайській композиторській творчості (Сунь Вей-бо, 2006; Winzenburg, 2018). Практично єдиним дослідженням, що оглядово представляє поліфонічні циклічні форми в китайській музиці, є дисертація Сунь Вей-бо, де основна увага автора націлена на розкриття своєрідності трактування цих творів «в умовах пентатоново-ладової системи музичного мислення» (Сунь Вей-бо, 
2006: 3). При цьому залишилися нерозкритими питання, присвячені розвитку китайської фортепіанної поліфонії в її основних жанрах; ролі поліфонічних творів в контексті фортепіанної творчості китайських композиторів; не розроблена внутрішньо-жанрова класифікація поліфонічних творів; не представлені еволюційні процеси розвитку китайської фортепіанної поліфонії; відсутні імена багатьох композиторів, які створили цікаві музичні зразки; не досліджені питання виконавської реалізації даних творів та ін.

Складність поліфонії в музиці сприяла тому, що у багатьох сучасних працях дане явище розглядається лише з позицій фізики і математики, наприклад, в статтях дослідницьких груп китайських вчених (Igarashi, Yuki \& Ito, Masashi \& Ito, Akinori, 2013; Weiwei, Zhang \& Zhe, Chen, \& Fuliang, Yin, 2016; Li, Xiaoquan et al., 2018). Безумовно, такий підхід не розкриває власне музичну складову поліфонічних жанрів. На досить відомому порталі шанувальників жанру «Kunst der Fuge» (С 2002-21) ${ }^{1}$ немає даних про жодного китайського композитора, що працює в області поліфонії.

Мета дослідження - виявити вклад китайських композиторів у створення фортепіанного поліфонічного репертуару XX - початку ХХІ століття.

Методологічною основою дослідження обрано комплексний підхід, який поєднує історичні методи, що відбивають еволюцію музичного мислення, з теоретичними, націленими на розкриття жанрово-стильової специфіки творів китайських авторів. Розгляд поліфонічних фортепіанних творів китайських композиторів грунтується на методі жанрово-стильового аналізу і теоретичних положеннях, розроблених в працях таких авторів, як П. Пешич (Pesic, 2017), В. Батанов (2020), Пен Чен (Пэн, Чэн, 2006), Фан Зуїнь (范醉嗯, 2004), Лі Хун (Li Hong, 2015), Ін Цзян (Ying Jiang, 2019), Чень Шуюнь (2020), Сунь Вей-бо (2006) та ін. Як відзначає Сунь Вей-бо, «в творчості композиторів Китаю музика поліфонічного складу розвивається під впливом двох факторів: іманентно-національних традицій, властивих ки-

${ }^{1}$ Kunst der Fuge / kunstderfuge.com (KDF) - веб-ресурс класичної музики у файлах mid (M.I.D.I./MIDI/.mid), (C) 2002-21. 
тайській музичній культурі (в тому числі фольклору), з одного боку, і загальноєвропейських, запозичених в якості еталонів трактування жанру і типів багатоголосся, - 3 іншого. Це обумовлює необхідність застосування такого системно-історичного дослідного методу, як художня компаративістика» (Сунь Вей-бо, 2006: 5).

Виклад основного матеріалу дослідження. XX століття відзначене зростанням ролі поліфонії в музиці. Відроджується інтерес до окремих поліфонічних жанрів, втілюваних у вигляді як самостійних творів, так і елементів великих форм, i, зокрема, до поліфонічних циклів - «малих», таких як Прелюдія і фуга; Прелюдія, токата і фуга; i «великих» - сюїти, партити, а також того типу циклів, які створював ще Й. С. Бах («Добре темперований клавір», «Мистецтво фуги»).

Звернення до старовинних поліфонічних жанрів і форм у творчості багатьох композиторів світу - це не просте копіювання, або ж «перенесення» їх з минулих століть до XX-XXI-го. Багато авторів прагнуть до органічного поєднання закономірностей, традиційно властивих поліфонічній музиці, і специфічних засобів виразності, що $€$ характерними для нашого часу і грунтуються на оновленні ладотональних, гармонічних, ритмічних та інших елементів музичної мови.

Західноєвропейська музика XX століття презентувала високі зразки поліфонії поза системою додекафонії. Творчість П. Хіндеміта одне з найпомітніших явищ поліфонії того часу - являє собою приклад послідовно тонального контрапунктичного стилю. П. Хіндеміт належить до творців великої тональної музики століття, який дав їй плідний новаторський розвиток. Зрозуміти новизну цього музичного напрямку багато в чому допомагає теоретична концепція П. Хіндеміта, викладена в його «Unterweising im Tonsatz» (Hindemith, 1940). Свою теорію ладотональної системи німецький композитор продемонстрував на практиці в створеному невдовзі після цієї теоретичної праці поліфонічному фортепіанному циклі «Ludus Tonalis». «Тональні, контрапунктичні і піаністичні вправи» - такий підзаголовок має цей твір. Цикл складається з 12-ти триголосних фуг, які чергуються 3 модулюючими інтерлюдіями і мають постлюдію.

«Поліфонічний» нахил «думки П. Хіндеміта» (Раппопорт, 1971: 188) не був винятковим явищем в музиці ХХ століття. Як ствер- 
джує Л. Бергер, одна $з$ причин великого інтересу музикантів цього часу до контрапункту криється у високому розвитку в нашу епоху наукового, математичного мислення, що народжує естетику досконалих пропорцій, строгих, ясних ліній і лаконічних функціональних форм (архітектура, прикладне мистецтво) (в кн.: Раппопорт, 1971: 189). У музиці це проявляється в зверненні низки композиторів до конструктивних принципів класицизму і до математично точних прийомів контрапунктичної техніки.

Серед численних творів поліфонічного плану, створених в радянській музиці XX століття, переважає фортепіанний поліфонічний цикл 3 фугою і власне фуга: 24 прелюдії і фуги Д. Шостаковича, 24 прелюдії і фуги, «Поліфонічний зошит», «Basso ostinato» Р. Щедріна, прелюдії і фуги Т. Назарової, М. Осокіна, І. Білорусца, фуги К. Сорокіна, В. Буніна, С. Разорьонова, В. Шмельова, В. Блинова 3 «Другої сюїти» та ін. Розвивають фугу і взагалі поліфонічні форми українські композитори В. Бібік («34 прелюдії і фуги») та М. Скорик («12 прелюдій і фуг»).

У другій половині XX століття значно розширюється географія створення нових поліфонічних композицій для фортепіано. Помітні новації в цій сфері вирізняють творчість численних композиторів з різних континентів і країн світу, таких як Чарльз Газзарі (Аргентина), Деніел Лео Сімпсон, Стівен Малиновські (США), Луї Калледж(Канада), Сигне (Японія), Сетрак Антон Сетракян (Ліван), Джорджо Паккьоні, Алессандро Сімонетто (Італія), Джеспер Хемдарв (Швейцарія), Маркус Джос Оскар (Іспанія), Янніс Галідакіс (Греція), Домінік Зедіві (Австрія), Лешек Вронські (Польща), Дмитро Либін (Білорусь) та ін.

Аргентинський композитор Чарльз А. Газзарі народився в Буенос-Айресі 1942 року в родині італійських емігрантів. Від 5 років навчався гри на фортепіано в Альми Мелгар, від 8 років у Вінченцо Скарамуцце, хоча всі його спроби стати концертуючим піаністом з різних причин не мали успіху. 3 ранніх років, захоплений музикою Й. С. Баха, хлопчик починає вправи в мистецтві контрапункту і 39 років пише досить багато музики. Свої твори він підписував псевдонімом Людвіг Кореллі. У 1965 році він приїхав до США. 
В Каліфорнії він плідно працював у 1969-1980 рр., хоча спочатку всі спроби донести його своєрідні твори в стилі нового Бароко до виконавців, диригентів і видавців часто закінчувалися невдачею і розчаруванням. 2001 року Людвіг Кореллі заснував звукозаписну фірму «Добре темперований грамофон».

Зараз, разом із дружиною Барбарою, він проживає у Вашингтоні, продовжує створювати ново- або псевдо-барокові твори, інші контрапунктні опуси, всього ж він написав близько 100 фуг. Найвідоміші 3 них для фортепіано: Шість прелюдій і фуг ор. 103 (D-Dur, F-Dur, g-moll, e-moll, d-moll, E-Dur) (1973-1974 pp.); Прелюдія і фуга c-moll (2005), Фуга «Вічний рух» ор. 52, Фуга «Танець чарівної свинини» op. 98, Фуга «Посмертна» ор. 99. Багато фуг написано також для органу: Фуга «Оазис» ор. 45, Фуга «Воскресіння» ор. 63, Фуга «Reedmaster» op. 64, Гіга-фуга «Нескінченна» ор. 100, Фуга «Готична» ор. 101.

Грецький композитор Янніс Галідакіс (нар. 1964), Афіни, Греція також видав свої нові поліфонічні твори для фортепіано: «Прелюдію і фугу» ля-мінор (1988) і «Фугу» до-мінор (2002).

Починаючи з 2000 року, стали з'являтися цікаві фортепіанні твори японського композитора Н. Т. Сигне (нар. 1969) у Хоккайдо, Японія. Перш за все, необхідно назвати його поліфонічний цикл «Чотири Прелюдії і Фуги в стилі Й. С. Баха» (Прелюдія і фуга до-дієз мінор, Прелюдія і фуга Мі-бемоль мажор, Прелюдія і фуга фа-мінор, Прелюдія і фуга Сі-бемоль мажор). 2001 року вийшли друком його Фуга для фортепіано фа-дієз мінор, Прелюдія соль-мінор, у 2002-му Фуга на тему японської народної пісні «Торіанс». 2003 року було видано ще чотири Прелюдії і фуги для фортепіано цього композитора.

T. Наусіка, видавець і власник сайту «Kunst der Fuge», відзначив роботи японського музиканта: «Опубліковані тут твори Н. T. (Signe) справжні дорогоцінні камені. Це чудовий приклад нової фуги; його стиль завжди дуже елегантний і врівноважений, а його фортепіанні твори - дуже цікаві» (Kunst der Fuge: The N.T./Signe's own page).

Китайські композитори також звертаються в своїй фортепіанній творчості до поліфонічних форм і поліфонічного способу розвитку музичного матеріалу. Використання поліфонії в китайській фортепіанній музиці обумовлене дещо іншими причинами, ніж у західноєв- 
ропейських композиторів, у першу чергу, воно пов'язане з особливостями китайського народного музичного мистецтва. Цей зв'язок виявляється не тільки в формах творчості та характері музичної мови, а й на значно глибшому рівні, в самому напрямі музичного мислення, що органічно тяжіє до лінеарності музичної тканини.

Традиційна китайська музика завжди була чисто мелодичною системою без будь-яких ознак поліфонії або гармонічного розвитку, навіть китайські пісні - одноголосні (Wiant, 1936: 1). Тільки один 3 китайських інструментів, шен, або «китайська флейта Пана» допускав видобування двох тонів одночасно. Цей цікавий маленький інструмент незмінно грає чисті кварти і квінти в паралельному русі. Подібна музика під назвою «органум» була відома на Заході протягом декількох століть, тоді як китайські музиканти грають на цьому інструменті, можливо, багато тисячоліть.

Наскільки відомо, до XX століття експериментів з поліфонічною обробкою китайського музичного матеріалу взагалі не проводилося, проте при бажанні, риси, властиві поліфонічній музиці, можна вгледіти в деяких елементах, наприклад, китайської опери. Так, в китайській опері скрипка часто грає вільний контрапункт до мелодії, але це скоріш імпровізація, а не відповідність прийнятим стандартам. Тому всі, хто згодом займався експериментами в сфері поліфонії в Китаї, були змушені покладатися виключно на західну техніку композиції.

Поступово виключно мелодичний тип музики, поширений в Китаї в минулому, під впливом європейських ідей і методів композиції поступається місцем гармонічному і поліфонічному. Більшість китайських композиторів-експериментаторів використовували гармонічні засоби розвитку мелодій, але такий підхід має тенденцію руйнувати природну спонтанність цих мелодій. Поліфонічна обробка краще зберігає мелодичну свободу, одночасно додаючи музиці різноманітності і навіть посилюючи ії оригінальну виразність.

Лінеарне мислення в західній традиційній поліфонічній музиці багато в чому аналогічне одноголосним принципам ладової системи юнь-гун-дяо (Пэн Чэн, 2006). Тому китайські композитори захоплюються такою технікою, пишуть багато поліфонічної музики - від стро- 
гого контрапункту до більш вільного викладу, від короткої п'єси до фуги, від чистої поліфонії до змішаної фактури. В цих творах, звісно, не тільки використовується західна поліфонічна техніка, а й присутня яскрава народна традиція. Особливості системи юнь-гун-дяо природніше зберігаються в поліфонічних творах, ніж в гомофонній музиці з ії функціональністю.

3 початку вивчення європейської музики китайськими композиторами вони роблять спроби поєднати принципи західноєвропейської мажоро-мінорної системи з китайською традицією. В цілому від взаємопроникнення системи юнь-гун-дяо та мажоро-мінорної системи китайська музика отримала багато нового, але міцно зберегла традиції. Це - процес збагачення й розвитку, вивчення та вдосконалення. Європейська техніка розвивається безперервно. В кінці XIX-го i XX столітті відбулися якісні зміни в музичній мові. Нові мови успадковують класично-романтичну традицію і нещадно руйнують іiі. Ці мови також впливають на китайську музичну творчість.

Перші зразки поліфонічних жанрів у творчості китайських композиторів з'явилися в довоєнний період, хоча творче становлення багатьох китайських композиторів, які писали поліфонічні твори для фортепіано, відбувалося вже в повоєнний час (друга половина XX століття). Однією з перших спроб стало засвоєння жанру інвенції, яке відбулося в творчості Сяо Шусяня, Ду Цяня, Сунь Юньїнна та ін. Це було обумовлено необхідністю створення педагогічного репертуару для системи музичної освіти, що динамічно розвивалася. Всі ці твори за своєю значимістю не виходять за рамки педагогічного репертуару, проте вони зіграли важливу роль в оволодінні поліфонічними прийомами і позитивно вплинули на розвиток багатоголосного мислення юних китайських музикантів.

Особливого поширення в Китаї отримали також поліфонічні п’єси програмного характеру. Так, п’єси «Флейта молодого пастушка», «Колискова пісня» Хе Лутіна, - одни з перших професійних композиторських зразків, у яких вже було продемонстровано поліфонічне письмо, засноване на європейській гармонічній системі в поєднанні 3 характерними для китайської музики інтонаційними оборотами. Результатом прагнення композиторів до збільшення форми стали ци- 
кли поліфонічних п’єс, які створили Хе Шаоін («Вісім китайських народних п’єс»), Чень Хуадо («Сорок поліфонічних п’єс на теми китайських народних пісень»), Сяо Шусянь («Поліфонічний цикл»).

Серед китайських композиторів, які часто зверталися в своїй фортепіанній творчості до фуги, слід назвати Лі Джун'юна, Юй Суяня, Чень Гана, Тянь Лейлея, Дуань Пінтая, Чжен Чжуна, Сяо Шусяня. Нерідко автори фуг об'єднують їх в міні-цикли, наприклад, «Три фуги» Тун Сяотін, «Дві маленькі фуги» Ван Пей’юань, «Дві фуги» Цзян Юаньлу, «Дві фуги» Цинь Тао. Фуги, написані в традиційних китайських ладах, відображають своєрідність національної композиторської школи. Ладова система юнь-гун-дяо - один з фрагментів китайської традиційної музичної культури, але процес іiї використання в XX столітті показує, що вона давно не може залишатися єдиною концепцією музичного мислення в Китаї, бо єдина можливість плідного розвитку полягає в рівноправному діалозі з західною культурою, iii звуковими системами, іiі художніми досягненнями.

Яскравими прикладами новаторського трактування малого циклу «Прелюдія і фуга» є «Чотири прелюдії і фуги» ор. 29 Дін Шанде; «13 прелюдій і фуг» Чен Жимінга; «Ташанська сюїта» (5 Прелюдій і фуг) Ван Лішаня; Прелюдія і фуга Рао Юяна і «Три прелюдії і фуги» Лін Хуа. Більшість композиторів демонструє в Прелюдіях і фугах тісний зв'язок китайських народно-ладових систем з західноєвропейським мажоро-мінором. В «13 прелюдіях і фугах» Чен Жимінг майстерно застосовує синтез додекафонної техніки, принципи політональності та поліладовості. Сміливим кроком композиторів Дін Шанде, Чен Жимінга, Лін Хуа стала відмова від об'єднання однією тональністю малого циклу «Прелюдія і фуга».

Фундатор китайського фортепіанного мистецтва Дін Шанде, який здобув музичну освіту у Франції, заклав також основи поліфонії в національній композиторській творчості. Він є автором таких фундаментальних робіт, як «Контрапункт старого стилю» (1952), «Подвійний контрапункт» (1954), «Нариси про техніку фуги» (1957), «Дослідження прийомів композиції» (1987). Фортепіанний цикл «Чотири прелюдії і фуги» ор. 29 був створений ним під впливом «ДТК» Й. С. Баха. Звернувшись до бахівської побудови малого полі- 
фонічного циклу «Прелюдія і фуга», композитор продовжив характерний для німецького генія імпровізаційний тип музичного мислення, прагнучи представити слухачеві «лабораторію» своєї творчої думки. Деякі дослідники вбачають також тісний зв'язок циклу з творчістю П. Хіндеміта, А. Онеггера, С. Прокоф'єва, вказуючи на ладове взаємопроникнення мажору і мінору, багатоскладність тональності, принцип зв'язку прелюдій і фуг через заключний тон (У На, 2009: 21), рух паралельними септакордами, нонакордами (Батанов, 2020: 65).

Незважаючи на відмінність тональностей в композиційній структурі циклу «Прелюдія і фуга», обидві фортепіанні п'єси складають самостійну поліфонічну дилогію. Подібна композиційна схема в цілому зберігається у всіх чотирьох прелюдіях і фугах Дін Шанде. Крім цього, композитор позначає кожну п'єсу програмою. Таким чином він підсилює принцип образно-драматургічного розгортання всередині міні-циклу. В фугах композитор сміливо використовує старовинні китайські лади.

Композитор Ван Лішань, навпаки, «зважився створити на національному матеріалі свого роду “китайський ДТК”. Подібно до того, як великий Й. С. Бах охопив всю систему мажорних и мінорних тональностей, Ван Лішань задумав втілити в тій самій формі малого циклу специфічну систему китайських пентатонових ладів» (Бай $€$, 2014: 9). Кожна прелюдія і фуга має авторську поетичну преамбулу та виконується attaca.

Чен Жимінг - видатний композитор і піаніст, автор багатьох теоретичних робіт з поліфонії. Першим композиторським досвідом Чен Жимінга в галузі поліфонічної музики для фортепіано став цикл «Вісім поліфонічних п’єс». Свої композиторські новації Чен Жимінг продовжив у циклі для фортепіано «Одинадцять поліфонічних п’єс». Фортепіанний цикл Чен Жимінга «13 прелюдій і фуг» є вищим досягненням композитора в області цієї поліфонічної форми. В поліфонічних творах композитора можна відзначити активний пошук нових для китайської музики композиційних технік, що поєднуються з поліфонічними принципами розвитку музичного матеріалу. Національний колорит у поліфонічних циклах Чен Жимінга виявляється за рахунок створення звукорядів, близьких за звучанням до пентатоніки, «мило- 
звучних тематичних побудов (наслідок впливу національного мелодизму)» (Чэнь Шуюнь, 2020: 16).

Цікаві поліфонічні композиції для фортепіано належать також іншим, різним за віком китайським композиторам: «12 двоголосних інвенцій в китайському стилі» і «12 триголосних симфоній в китайському стилі» Чен Ченкуанга (нар. 1932); «Сюїта в сінцзянському поліфонічному стилі для юнацтва» (1990) Ма Гуй (нар. 1932). Великий інтерес в Китаї викликали твори більш молодого композитора Жанга Хонгбінга (нар. 1967): «11 сінцзянських фортепіанних фуг» (2003), з яких одна - двоголосна, чотири - триголосні, три п’ятиголосні, одна - шестиголосна, одна - восьмиголосна; а також «Прелюдія і фуга для фортепіано в чотири руки» (2002).

Висновки. Поліфонічні твори для фортепіано китайських композиторів відіграли значну роль в створенні національного фортепіанного репертуару. Китайські композитори в повній мірі оволоділи мистецтвом сучасного контрапункту, що представлений жанрами поліфонічної програмної п’єси (Хе Лутін), інвенції (Сяо Шусянь, Ду Цянь, Сунь Юньїнн, Чен Ченкуанг), поліфонічної сюїти (Ма Гуй), великого поліфонічного циклу (Хе Шаоін, Чень Хуадо, Сяо Шусянь), фуги (Лі Джунюн, Юй Суянь, Чень Ган, Тянь Лейлей, Дуань Пінтай, Чжен Чжун), малого циклу «Прелюдія і фуга» (Дін Шанде, Чен Жимінг, Ван Лішань).

Першими зразками поліфонічних форм в китайській фортепіанній музиці слід вважати твори Хе Лутіна, Лао Чжичена, Дин Шанде та ін. За ними розвивати поліфонічне фортепіанне мистецтво продовжили Сяо Шусянь, Ду Цянь, Сунь Юньїнн, Хе Шаоін, Чень Хуадо, Тун Сяотін, Чен Жимінг, Ван Пейюань, Ван Лішань, Рао Юян, Лін Хуа, Чу Зонгфен, Ло Чжунжун, Юй Сусянь та ін. Творчо освоюючи і переосмислюючи досвід західних поліфоністів, китайські композитори створили мистецтво нової поліфонії, наситивши його національними рисами, міцно зв'язавши з витоками китайської національної музики, надавши китайській фортепіанній поліфонії новий зміст, а, почасти, й форму.

Фуга та інші поліфонічні форми отримали особливо широке поширення, зокрема, в другій половині XX століття. Фортепіанні фуги 
Дін Шанде, Чу Зонгфена, потужні поліфонічні концепції Ван Лішаня, Чен Жимінга, Лін Хуа в рівній мірі містять в собі особливості мислення китайських композиторів, що відбиваються у поєднанні національного характеру музики, сучасних способів тематичної розробки матеріалу, розвинених поліфонічних прийомів голосоведіння, специфіці музичної мови.

У XXI столітті в китайському музичному друці з'явилися натхненні, глибоко змістовні твори Чен Ченкуанга, Ма Гуй, Жанга Хонгбінга та ін. Створюються нові поліфонічні форми і відбуваються якісні зміни в способах використання поліфонічних методів розробки музичного тематизму на основі багатого конкретного музичного матеріалу, представленого, насамперед, невичерпним творчим потенціалом китайської фольклорної традиції, в опорі на досягнення світової музичної класики.

Поліфонічний спосіб розробки музичного матеріалу у китайських композиторів стає засобом виразності в моменти найбільшої творчої заглибленості, драматизації музичного змісту. Засоби, які надає для цього класична західноєвропейська поліфонія в тісній взаємодії $з$ народними традиціями, виявляються найбільш близькими китайським музикантам, в порівнянні 3 можливостями використання гомофонно-гармонічного стилю або стилю західної поліфонії.

Фуга різноманітно представлена в творчості китайських композиторів і як частина поліфонічного циклу, і як самостійний твір. Цей жанр є вершиною розвитку поліфонії в китайській фортепіанній музиці. Поряд 3 природним творчим натхненням, в фузі поєдналися всі високі досягнення професійної музикальної думки; в ній проявилися і особливості музичного мислення багатьох китайських композиторів; в ній, як в дзеркалі, відбилися і досягнення тривалого періоду еволюції народного творчого генія. Фуги, написані в традиційних китайських ладах, несуть риси національної композиторської школи і відображають їі своєрідність.

Представлене дослідження відкриває перспективи для подальшого поглибленого аналізу творчості китайських композиторів в царині поліфонічної музики для фортепіано із залученням конкретних зразків різних іiї жанрів. Автор даної статті сподівається, що поліфо- 
нічні твори для фортепіано композиторів його рідної країни зацікавлять українських виконавців і посядуть гідне місце в їхньому піаністичному репертуарі.

\section{ЛІТЕРАТУРА}

Бай, Є. (2014). Китайська фортепіанна музика в контексті інтеграційних процесів світового музичного мистецтва. (Автореферат дис. ... канд. мистецтвознавства). Харківський національний університет мистецтв імені І. П. Котляревського. Харків.

Батанов, В. (2020). Европейские традиции фортепианной музыки в творчестве китайских композиторов XX века. Вісник Національної академії керівних кадрів культури і мистецтв, 1, 61-69. DOI: https://doi.org/10.32461/22263209.1.2020.196567

Пэн, Чэн (2006). Китайская традииионная ладовая система и ее применение 6 ХХ веке. Москва: МПГУ.

Раппопорт, Л. (Сост.). (1971). Теоретические проблемы музыкальных жанров и форм. А. Сохор, Ю. Холопова (Общ. ред.). Москва: Музыка.

Сунь, Вэй-бо. (2006). Полифонический цикл в фортепианном творчестве китайских композиторов: традииии и новаторство. (Автореферат дис. ... канд. искусствоведения). Белорусская государственная академия музыки. Минск.

У, На. (2009). Фортепианная музыка Дин Шан Дэ: сопряжение китайской национальной традиции с современными приёмами европейского письма. (Автореферат дис. ... канд. искусствоведения). Санкт-Петербургская государственная консерватория им. Н. А. Римского-Корсакова. Санкт-Петербург.

Чэнь, Шуюнь. (2020). Фортепианное творчество китайских композиторов XX - начала XXI веков: основные стилевые направления. (Автореф. дис. .... канд. искусствоведения). Нижегородская государственная консерватория им. М. И. Глинки. Нижний Новгород.

Hindemith, Paul. (1940). Unterweisung im Tonsatz. (2 Teile in 2 Bänden). Mainz: B. Schott's Söhne.

Igarashi, Yu., Ito, M., \& Ito, A. (2013). Evaluation of Sinusoidal Modeling for Polyphonic Music Signal. In 2013 Ninth International Conference on Intelligent 
Information Hiding and Multimedia Signal Processing, (pp. 464-467). Beijing: IEEE. DOI: 10.1109/IIH-MSP.

Kunst der Fuge / kunstderfuge.com (C 2002-21). The largest resource of classical music in .mid files. Retrieved from http://kunstderfuge.com

Li, Hong. (2015). The Practice of Integration Guangxi Polyphonic Folk Music into Chorus Singing Teaching for Normal University Students. Proceeding from International Conference on Advanced Education and Management (ICAEM 2015), May 15-16, Guilin, China, 488-492. ISBN: 978-1-60595-252-9.

Li, Xiaoquan, Yan, Yijun, Ren, Jinchang, Zhao, Huimin, Zhao, Sophia, Soraghan, John, \& Durrani, Tariq (2018). Knowledge based fundamental and harmonic frequency detection in polyphonic music analysis. In Communications, Signal Processing, and Systems. Springer, CHN, 591-599. ISBN 9789811065705; DOI: https://doi.org/10.1007/978-981-10-6571-2_72

Pesic, P. (2017). Polyphonic Minds: Music of the Hemispheres. London: MIT Press.

Weiwei, Zhang, Zhe, Chen, \& Fuliang, Yin. (2016). Main melody extraction from polyphonic music based on modified Euclidean algorithm. Applied Acoustics, 112, 70-78. https://doi.org/10.1016/j.apacoust.2016.04.023

Wiant, B. M. (1936). Possibilities of Polyphonic Treatment of Chinese Tunes. (Master of Arts thesis). Boston University. Boston.

Winzenburg, J. (2018). A New Multivoiced World: Polyphony and the First Chinese-Western Fusion Concerto. Journal of musicological research, 37 (3), 209-238. DOI10.1080/01411896.2018.1482486

Ying, Jiang. (2019). Reviving the Beauty of Bach's Music - On the Teaching of Bach's Polyphonic Works. Proceedings of the 2nd International Seminar on Education Research and Social Science (ISERSS 2019). Series Advances in Social Science, Education and Humanities Research, (pp. 156-159). Atlantis Press. Retrieved from https://www.atlantis-press.com/proceedings/ iserss-19/125911027, doi https://doi.org/10.2991/iserss-19.2019.41

范醉恩 [Фан Зуїнь]. (2004). 民间音乐复音中国. 北京 [Народне музичне багатоголосся Китаю]. Пекін: [Китайська консерваторія]. 


\section{Zhang Mengzhe}

Postgraduate student at the Department of Interpretation and Music Analysis, Kharkiv I. P. Kotlyarevsky National University of Arts; e-mail:764735303@qq.com ORCID iD 0000-0003-0988-4263

\section{POLYPHONIC GENRES IN PIANO CREATIVITY OF CHINESE COMPOSERS}

Statement of the problem. The twentieth century marked an increased interest in polyphonic music. The geography of polyphonic works for piano expanded significantly and a creative development of many Chinese composers, writing polyphonic piano pieces, took place. Today, polyphonic pieces make up a significant part of the piano repertoire in China, but they are little studied by musicologists and performers.

The objective of this study - to reveal the contribution of Chinese composers to the creation of polyphonic piano repertoire of the $X X$-early XXI century.

Analysis of the research and publications on the theme. A large number of modern authors study polyphony from the point of physical and mathematical research methods (Igarashi, Yu. \& Ito, Masashi \& Ito, Akinori, 2013; Weiwei, Zhang \& Zhe, Chen, \& Fuliang, Yin, 2016; Li, Xiaoquan et al. others, 2018). This approach does not reveal the factual musical component of polyphonic genres. In the 20th century, musicologists explored polyphony in musical folklore (Wiant, 1936; Fan Zuyin, 2004; Li Hong, 2015) and in professional Chinese composing (Sun Wei-bo, 2006, Winzenburg, 2018).

The scientific novelty. This article studies the role of Chinese composers in the development of the world polyphonic piano repertoire of the XX-early $X X I$ century. The methodological basis for the analysis of polyphonic works was the theoretical concepts of P. Hindemith, Peng Cheng, Fang Zuin, Li Hong, Sun Wei-bo.

The results of the study. The research outcomes demonstrate the evolutionary development of the genre diversity of Chinese piano polyphony as well as those composers who created magnificent musical pieces. 
Conclusions. Chinese composers have fully mastered the art of modern counterpoint, represented by the genres of polyphonic program pieces (He Lu Ting), invention (Xiao Shu Xian, Du Qian, Sun Yun Yin, Chen Chen Quang), polyphonic suite (Ma Gui), large polyphonic cycle ( He Shao, Chen Hua Do, Xiao Shu Xian), fugue (Li Jun Yong, Yu Su Yan, Chen Gang, Tian Lei Lei, Duan Ping Tai, Zheng Zhong, Xiao Shu Xian) and small cycle "Prelude and Fugue" (Ding Shan Te, Chen Zhi Ming, Wang Li Shan). Creatively assimilating and rethinking the experience of Western polyphonists, Chinese composers have filled their polyphonic works with national features, firmly linking them with the origins of Chinese traditional and folk music. The polyphonic way of transmitting musical material becomes the most expressive at the moments of profound creativity and musical dramatization.

Key words: polyphony; Chinese piano music; Chinese composers; invention; fugue; suite; prelude and fugue.

\section{REFERENCES}

Bai, Ye. (2014). Chinese piano music in the context of integration processes of world music art. (Extended abstract of Candidate diss.). Kharkiv I. P. Kotlyarevsky National University of Arts. Kharkiv [in Ukrainian].

Batanov, V. (2020). European traditions of piano music in the works of Chinese composers of the twentieth century. Bulletin of the National Academy of Management of Culture and Arts, 1,61-69. DOI: https://doi.org/10.32461/22263209.1.2020.196567 [in Russian].

Chen, Shuyun. (2020). Piano creativity of Chinese composers of the XX-early $X X I$ centuries: the main stylistic directions. (Extended abstract of Candidate diss.). Nizhny Novgorod State Conservatory named after Mikhail Glinka: Nizhny Novgorod [in Russian].

Fan, Zuyin (2004). Folk musical polyphony of China. Beijing: China Conservatory [in Chinese].

Hindemith, P. (1940). Instruction in composition. (2 parts in 2 volumes). Mainz: B. Schott's Söhne [in German].

Igarashi, Yu., Ito, M., \& Ito, A. (2013). Evaluation of Sinusoidal Modeling for Polyphonic Music Signal. In 2013 Ninth International Conference on Intelligent Information Hiding and Multimedia Signal Processing, (pp. 464-467). Beijing: IEEE. DOI: 10.1109/IIH-MSP [in English]. 
Kunst der Fuge / kunstderfuge.com (C 2002-21). The largest resource of classical music in .mid files. Retrieved from http://kunstderfuge.com [in English].

Li, Hong. (2015). The Practice of Integration Guangxi Polyphonic Folk Music into Chorus Singing Teaching for Normal University Students. Proceeding from International Conference on Advanced Education and Management (ICAEM 2015), May 15-16, Guilin, China, 488-492. ISBN: 978-1-60595252-9 [in English].

Li, Xiaoquan, Yan, Yijun, Ren, Jinchang, Zhao, Huimin, Zhao, Sophia, Soraghan, John, \& Durrani, Tariq (2018). Knowledge based fundamental and harmonic frequency detection in polyphonic music analysis. In Communications, Signal Processing, and Systems. Springer, CHN, 591-599. ISBN 9789811065705; DOI: https://doi.org/10.1007/978-981-10-6571-2_72

Peng, Cheng (2006). The Chinese Traditional Modal System and Its Application in the 20th Century. Moscow: MPGU [Moscow Pedagogical State University] [in Russian].

Pesic, P. (2017). Polyphonic Minds: Music of the Hemispheres. London: MIT Press.

Rappoport, L. (Ed.-comp.). (1971). Theoretical problems of musical genres and forms. A. Sokhor, Yu. Kholopov (Common ed.). Moscow: Music [in Russian]. Sun, Wei-bo. (2006). Polyphonic Cycle in the Piano Creativity of Chinese Composers: Tradition and Innovation. (Extended abstract of Candidate diss.). Belarusian State Academy of Music. Minsk [in Russian].

Weiwei, Zhang, Zhe, Chen, \& Fuliang, Yin. (2016). Main melody extraction from polyphonic music based on modified Euclidean algorithm. Applied Acoustics, 112, 70-78. https://doi.org/10.1016/j.apacoust.2016.04.023

Wiant, B. M. (1936). Possibilities of Polyphonic Treatment of Chinese Tunes. (Master of Arts thesis). Boston University. Boston [in English].

Winzenburg, J. (2018). A New Multivoiced World: Polyphony and the First Chinese-Western Fusion Concerto. Journal of musicological research, 37 (3), 209-238. DOI 10.1080/01411896.2018.1482486 [in English].

Wu, Na. (2009). Ding Shan Te's Piano Music: Combining Chinese National Tradition with Modern Methods of European Writing. (Extended abstract of Candidate thesis). St. Petersburg N. A. Rimsky-Korsakov State Conservatory. St. Petersburg [in Russian]. 
Ying, Jiang. (2019). Reviving the Beauty of Bach's Music - On the Teaching of Bach's Polyphonic Works. Proceedings of the 2nd International Seminar on Education Research and Social Science (ISERSS 2019). Series Advances in Social Science, Education and Humanities Research, (pp. 156-159). Atlantis Press. Retrieved from https://www.atlantis-press.com/proceedings/ iserss-19/125911027, doi https://doi.org/10.2991/iserss-19.2019.41 [in English].

Стаття надійшла до редакиії 19 вересня 2021 p. 